\title{
Cell-Free DNA: Hope and Potential Application in Cancer
}

\begin{abstract}
Yan-yan Yan ${ }^{1,2 \dagger}$, Qiao-ru Guo ${ }^{2,3 \dagger}$, Feng-hua Wang ${ }^{4 \dagger}$, Rameshwar Adhikari ${ }^{5}$, Zhuang-yan Zhu ${ }^{1}$, Hai-yan Zhang ${ }^{1}$, Wen-min Zhou ${ }^{2}$, Hua $\mathrm{Yu}^{6 *}$, Jing-quan $\mathrm{Li}^{3 *}$ and Jian-ye Zhang ${ }^{1,2,3 *}$

${ }^{1}$ School of Medicine, Shanxi Datong University, Datong, China, ${ }^{2}$ Key Laboratory of Molecular Target and Clinical Pharmacology and the State Key Laboratory of Respiratory Disease, School of Pharmaceutical Sciences and the Fifth Affiliated Hospital, Guangzhou Medical University, Guangzhou, China, ${ }^{3}$ The First Affiliated Hospital, Hainan Medical University, Haikou, China, ${ }^{4}$ Guangzhou Institute of Pediatrics/Guangzhou Women and Children's Medical Center, Guangzhou Medical University, Guangzhou, China, ${ }^{5}$ Research Centre for Applied Science and Technology, Tribhuvan University, Kirtipur, Nepal, ${ }^{6}$ State Key Laboratory of Quality Research in Chinese Medicine, Institute of Chinese Medical Sciences, Avenida da Universidade, Taipa, China
\end{abstract}

\section{OPEN ACCESS}

Edited by:

Wei Zhao,

Chengdu Medical College, China

Reviewed by:

Hongming Miao,

Army Medical University, China

Yi-Chao Zheng,

Zhengzhou University, China

*Correspondence:

Jian-ye Zhang

jianyez@163.com

Jing-quan Li

lijingquan2008@163.com

Hua Yu

bcalecyu@um.edu.mo

tThese authors have contributed equally to this work

Specialty section:

This article was submitted to Molecular and Cellular Oncology, a section of the journal Frontiers in Cell and Developmental

Biology

Received: 08 December 2020

Accepted: 20 January 2021

Published: 22 February 2021

Citation:

Yan Y-y, Guo Q-r, Wang F-h, Adhikari R, Zhu Z-y, Zhang $\mathrm{H}-\mathrm{y}$,

Zhou W- $m$, Yu H, Li J-q and Zhang J-y (2021) Cell-Free DNA: Hope and Potential Application in Cancer. Front. Cell Dev. Biol. 9:639233. doi: $10.3389 /$ fcell.2021.639233
Cell-free DNA (cfDNA) is easily accessible in peripheral blood and can be used as biomarkers for cancer diagnostics, prognostics, and therapeutics. The applications of cfDNA in various areas of cancer management are attracting attention. In this review article, we discuss the potential relevance of using cfDNA analysis in clinical oncology, particularly in cancer screening, early diagnosis, therapeutic evaluation, monitoring disease progression; and determining disease prognosis.

Keywords: cell-free DNA (cfDNA), cancer, diagnosis, therapeutic effect evaluation, liquid biopsy

\section{INTRODUCTION}

Cell-free DNA (cfDNA) is released from cells into the circulatory system throughout the body. It was first discovered by Mandel and Métais in 1948 (Mandel and Metais, 1948). cfDNA can be found in plasma (Mandel and Metais, 1948) and other body fluids such as, cerebral spinal fluid (CSF) (Rhodes et al., 1994), pleural fluid (Sriram et al., 2012), urine (Sidransky et al., 1991; Zhang et al., 1999), saliva (Mithani et al., 2007; Wang et al., 2015), and others. Previous studies indicated that most of the plasma cfDNA molecules originate from the hematopoietic system in healthy individuals (Lui et al., 2002; Sun et al., 2015). However, in certain physiological or pathological conditions, such as pregnancy, organ transplantation, and cancers, the related/affected tissues could release additional DNA into peripheral circulation (Leon et al., 1977; Lo et al., 1997, 1998). Therefore, detection of cfDNA in peripheral blood could identify abnormalities of individuals in a noninvasive manner. In recent years, a variety of technologies have emerged based on the analysis of cfDNA for noninvasive prenatal testing (NIPT) (Lo et al., 1997, 2007; Hyett et al., 2005; Wong and Lo, 2015; Hudecova and Chiu, 2017; Bianchi and Chiu, 2018; Malan et al., 2018; Vivanti et al., 2019; Zhang J. et al., 2019), monitoring organ transplantation (Lo et al., 1998; Gielis et al., 2015; Gala-Lopez et al., 2018; Sherwood and Weimer, 2018), and detecting immune diseases (Zhang et al., 2014; Beranek et al., 2017; Dunaeva et al., 2018; Xu et al., 2018; Duvvuri and Lood, 2019), as well as cancers.

Analysis of protein biomarkers and nucleic acids has become very popular for cancer diagnosis (Huang et al., 2020), risk stratification, and molecular targeting therapeutics (Zhang D. et al., 2019; Wang et al., 2020). However, many biomarker studies are based on analysis of tumor tissues that are obtained from invasive surgical procedures and may not be accessible in some cases. New approaches with noninvasive procedure are urgently needed. cfDNA analysis has attracted 
increasing attention because of its easy accessibility, noninvasive nature, and potential tumor specificity through quantitative detection or specific sequencing. In Table 1, we summarized several cfDNA applications in different diseases. Therefore, considerable efforts have been made to explore the potential application of cfDNA in clinical cancer management. The sensitivity of cfDNA analytic technologies has been greatly improved due to the advancement of molecular biology and next-generation sequencing (NGS) approaches. cfDNA analysis is widely used in various areas of cancer diagnostics and prognostics, as well as cancer drug resistance, and early screening.

Cancer patients usually have a high level of cfDNA in their serum or plasma as a result of cellular necrosis or apoptosis, because tumor cells divide faster than normal cells, and cfDNAs are released in a high proportion (Sorenson et al., 1994; Vasioukhin et al., 1994; Raja et al., 2018). The fraction of cfDNA that derived from tumor cells is named circulating tumor DNA (ctDNA) (Leon et al., 1977; Shu et al., 2017). In recent years, both cfDNA and ctDNA have gotten huge attention as novel blood biomarkers, as quantification and kinetic analysis of cfDNA (Diehl et al., 2008) and molecular profiling of ctDNA have suggested their predictive and prognostic values (Iizuka et al., 2006; Tokuhisa et al., 2007). Several liquid biopsy tests, designed for the identification of cancer-specific mutations, have been recommended as companion diagnostic (CDx) tests, by the European Medicines Agency (EMA) and Food and Drug Administration (FDA) of USA, to guide therapeutic decision making. Such tests include the cobas EGFR Mutation Test for non-small lung cancer or BRAC Analysis CDx for breast and ovarian cancer. Epi proColon ${ }^{\circledR}$, based on the analyses of the methylation status of the SEPT9 gene, is the first and only FDAapproved blood-based test for the detection of colorectal cancer. The applications of cfDNA in cancer are shown in Figure 1.

\section{CfDNA FOR CANCER DIAGNOSIS AND EARLY SCREENING}

Analysis of cfDNA has become a promising noninvasive approach in cancer diagnosis (Haber and Velculescu, 2014; Siravegna et al., 2017). The applications of cfDNA-based cancer liquid biopsy in recent year are summarized in Table 2. cfDNA comes from fragmented DNA released by cells into the circulation, most commonly as a result of cell death. In healthy individuals, the blood cfDNA originates from germline DNA released by normal cells. In cancer patients, a portion of cfDNA comes from tumor cells, named circulating-tumor DNA (ctDNA), which may contain tumor-specific variations corresponding to the patient's tumor, such as mutated tumor suppressor genes or oncogenes (Wang et al., 2004), microsatellite instability (MSI) (Shaw et al., 2000), and DNA methylation (Fujiwara et al., 2005). Based on some quantitative studies, it is found that the concentration of cfDNA in healthy subjects is between 0 and $100 \mathrm{ng} / \mathrm{ml}$ of blood with an average of $30 \mathrm{ng} / \mathrm{ml}$, whereas the concentration of cfDNA in the blood of cancer patients varies from 0 to $1,000 \mathrm{ng} / \mathrm{ml}$, with an average of 180 ng/ml (Leon et al., 1977; Esposito et al., 2017; Phallen et al., 2017).

TABLE 1 | Summary of cfDNA applications in different diseases.

\begin{tabular}{|c|c|c|c|c|c|}
\hline Disease & Marker(s) & Technical method & Clinical significance & Sample & References \\
\hline $\begin{array}{l}\text { Non-invasive prenatal } \\
\text { testing (NIPT) }\end{array}$ & Fetal DNA & $\begin{array}{l}\text { PCR, sequencing; Y-PCR } \\
\text { assay }\end{array}$ & $\begin{array}{l}\text { Trisomy } 13,18 \text {, or } 21 \text {; fetal } \\
\text { achondroplasia; dominant } \\
\text { monogenic diseases; } \\
\text { thalassemias; determination } \\
\text { of fetal sex }\end{array}$ & $\begin{array}{l}\text { Maternal plasma or } \\
\text { serum }\end{array}$ & $\begin{array}{l}\text { Lo et al., 1997; Wong } \\
\text { and Lo, 2015; } \\
\text { Hudecova and Chiu, } \\
\text { 2017; Bianchi and } \\
\text { Chiu, 2018; Malan } \\
\text { et al., 2018; Vivanti } \\
\text { et al., 2019; Zhang J. } \\
\text { et al., 2019 }\end{array}$ \\
\hline Organ transplantation & $\begin{array}{l}\text { Donor-specific } \\
\text { DNA }\end{array}$ & PCR, Sequencing & $\begin{array}{l}\text { Monitoring organ } \\
\text { transplantation }\end{array}$ & $\begin{array}{l}\text { Plasma of transplant } \\
\text { recipients }\end{array}$ & $\begin{array}{l}\text { Lo et al., 1998; Gielis } \\
\text { et al., 2015; } \\
\text { Gala-Lopez et al., } \\
\text { 2018; Sherwood and } \\
\text { Weimer, } 2018\end{array}$ \\
\hline Immune diseases & $\begin{array}{l}\text { Elevated levels of } \\
\text { cfDNA; LINE-1 } \\
\text { hypermethylation }\end{array}$ & $\begin{array}{l}\text { Picogreen Kit; qPCR } \\
\text { (quantitative real-time PCR); } \\
\text { methylation-specific } \\
\text { quantitative PCR, } \\
\text { sequencing }\end{array}$ & $\begin{array}{l}\text { Detecting and assessing } \\
\text { systemic lupus } \\
\text { erythematosus (SLE) } \\
\text { disease activity and } \\
\text { monitoring treatment; } \\
\text { exacerbated psoriasis; } \\
\text { relapsing remitting multiple } \\
\text { sclerosis; autoimmune } \\
\text { rheumatic diseases }\end{array}$ & $\begin{array}{l}\text { Plasma or serum of } \\
\text { patients }\end{array}$ & $\begin{array}{l}\text { Zhang et al., 2014; } \\
\text { Beranek et al., 2017; } \\
\text { Dunaeva et al., 2018; } \\
\text { Xu et al., 2018; Durvuri } \\
\text { and Lood, 2019 }\end{array}$ \\
\hline Cancer & $\begin{array}{l}\text { Circulating tumor } \\
\text { DNA }\end{array}$ & PCR; sequencing & $\begin{array}{l}\text { Diagnosis; predicting } \\
\text { response to therapy; } \\
\text { indicating prognosis }\end{array}$ & $\begin{array}{l}\text { Plasma and serum of } \\
\text { cancer patients }\end{array}$ & $\begin{array}{l}\text { Wan et al., 2017; Wang } \\
\text { and Xu, 2019; Fares } \\
\text { et al., } 2020\end{array}$ \\
\hline
\end{tabular}




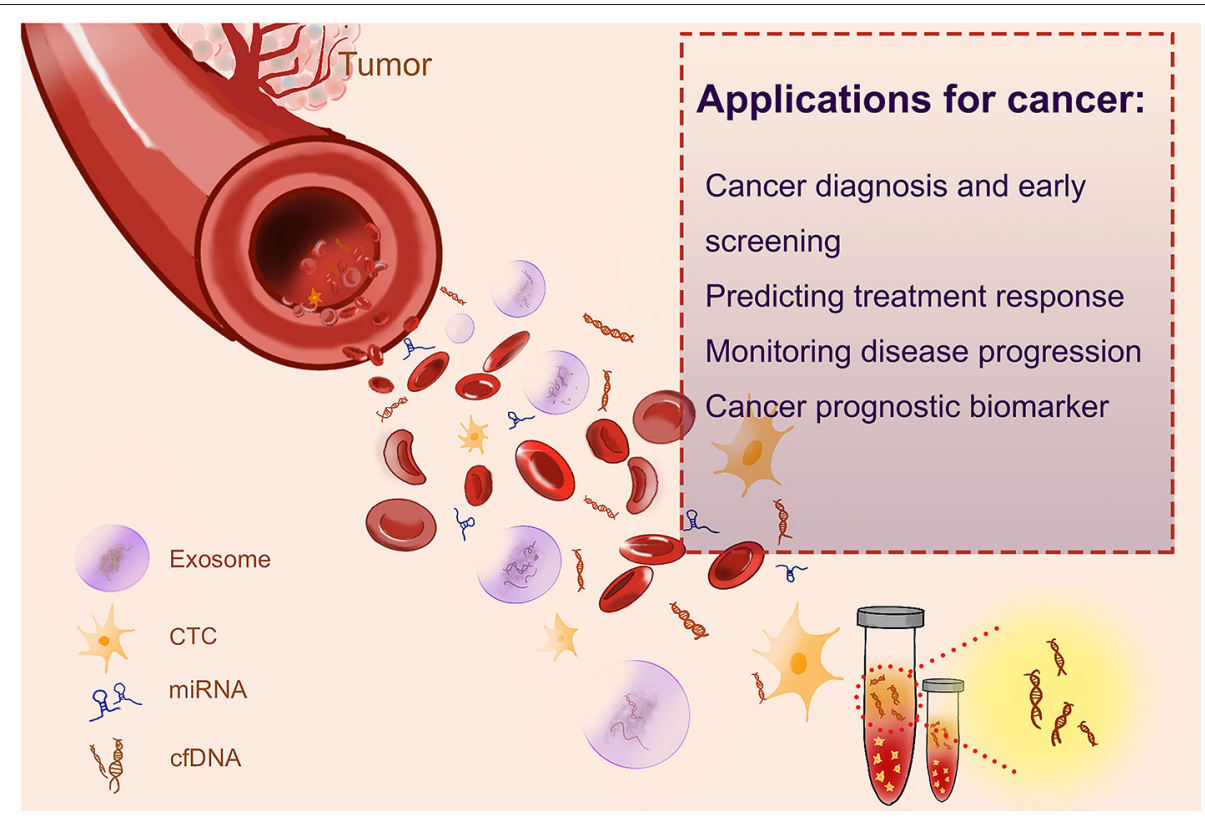

FIGURE 1 | The applications of cfDNA in cancer.

It is reported that the size (Kamat et al., 2006; Gorges et al., 2012) and stage (Nawroz et al., 1996; Bettegowda et al., 2014) of tumors are correlated with the blood level of ctDNA. There are 100-1,000 copies of ctDNA per $5 \mathrm{~mL}$ of blood in patients with stage IV or advanced tumors, and only 10 copies of ctDNA in those with early stage cancers (Bettegowda et al., 2014). Additional amount of ctDNA is also seen in patients with metastatic tumors. Quantification on patients with relapsed high-grade serous ovarian carcinoma (HGSOC) has indicated an increase of six copies of ctDNA per $\mathrm{mL}$ blood for an additional 1 $\mathrm{cm}^{3}$ of tumor (Parkinson et al., 2016).

\section{Hematological Malignancies}

Some studies analyzed the cfDNA in hematologic malignancies. TP53 (G249 T, G249A, T176C, C250 T, and T238G) and nucleophosmin mut.A (a duplication of the TCTG at positions 956-959) mutations were found in cfDNA from patients with acute myelogenous leukemia (AML) and non-Hodgkin's lymphoma (NHL) (Hosny et al., 2009; Quan et al., 2015). The diagnosis of lymphomas in the central nervous system (CNS) is complex, and obtaining brain biopsy is of high risk of complications. Biomarkers in blood and cerebrospinal fluid could be potential tools for early diagnosis of lymphomas. Zorofchian et al. examined a patient with suspected CNS lymphoma by detecting MYD88 mutation (L265 P and V217 F) in the cerebrospinal fluid (CSF). They suggested that analysis of cfDNA in CSF could be a minimally invasive diagnostic tool for CNS lymphomas (Zorofchian et al., 2018). Other studies also proved the potential of detecting MYD88 mutation in CSF as well as in plasma (Fontanilles et al., 2017; Hiemcke-Jiwa et al., 2019). Patients with lymphoma showed a higher level of cfDNA in their plasma than did healthy subjects. Hohaus et al. (2009) reported that the cfDNA level is different in patients with diffuse large B-cell lymphoma (DLBCL), mantle cell lymphoma (MCL), and Hodgkin's lymphoma (HL). Nucleosomal DNA (ncDNA) is another source of cfDNA. The changes of ncDNA corresponded with response to treatment, suggesting that ncDNA could be a valuable biomarker for hemopoietic cancer patients (Mueller et al., 2006). Taken together, cfDNA can be used for detecting gene mutation and chromosomal abnormalities. The level of blood cfDNA might serve as an important noninvasive diagnostic tool for patients with hemopoietic cancers.

\section{Thyroid Cancer}

Salvianti et al. adopted a quantitative real-time PCR (qPCR) approach based on quantification of two amplicons with different lengths (67 and $180 \mathrm{bp}$ ) to evaluate the integrity index 180/67. They reported that the cfDNA integrity index 180/67 can monitor cfDNA fragmentation in thyroid cancer. Thus, the cfDNA integrity index 180/67 could be used as a circulating biomarker for the diagnosis of thyroid nodules. The quantity of cfDNA is higher in patients affected by nodular thyroid diseases than in healthy individuals. Importantly, the cfDNA integrity index was higher in patients with cytologically diagnosed thyroid carcinoma (Thy4/Thy5) than in individuals with benign nodules (Thy2) (Salvianti et al., 2017).

\section{Colorectal Cancer}

It is reported that KRAS mutation can be identified using cfDNA. Wang et al. uncovered KRAS mutations (in codons 12, 13, and 61 ) in patients with stage I-IV colorectal cancer and found these mutations in blood samples. They showed that there are about $45 \%$ of concordance between the CRC tumor tissues and cfDNA. KRAS mutations are not found in cfDNA of healthy subjects 
TABLE 2 | Summary of cfDNA-based cancer liquid biopsy studies.

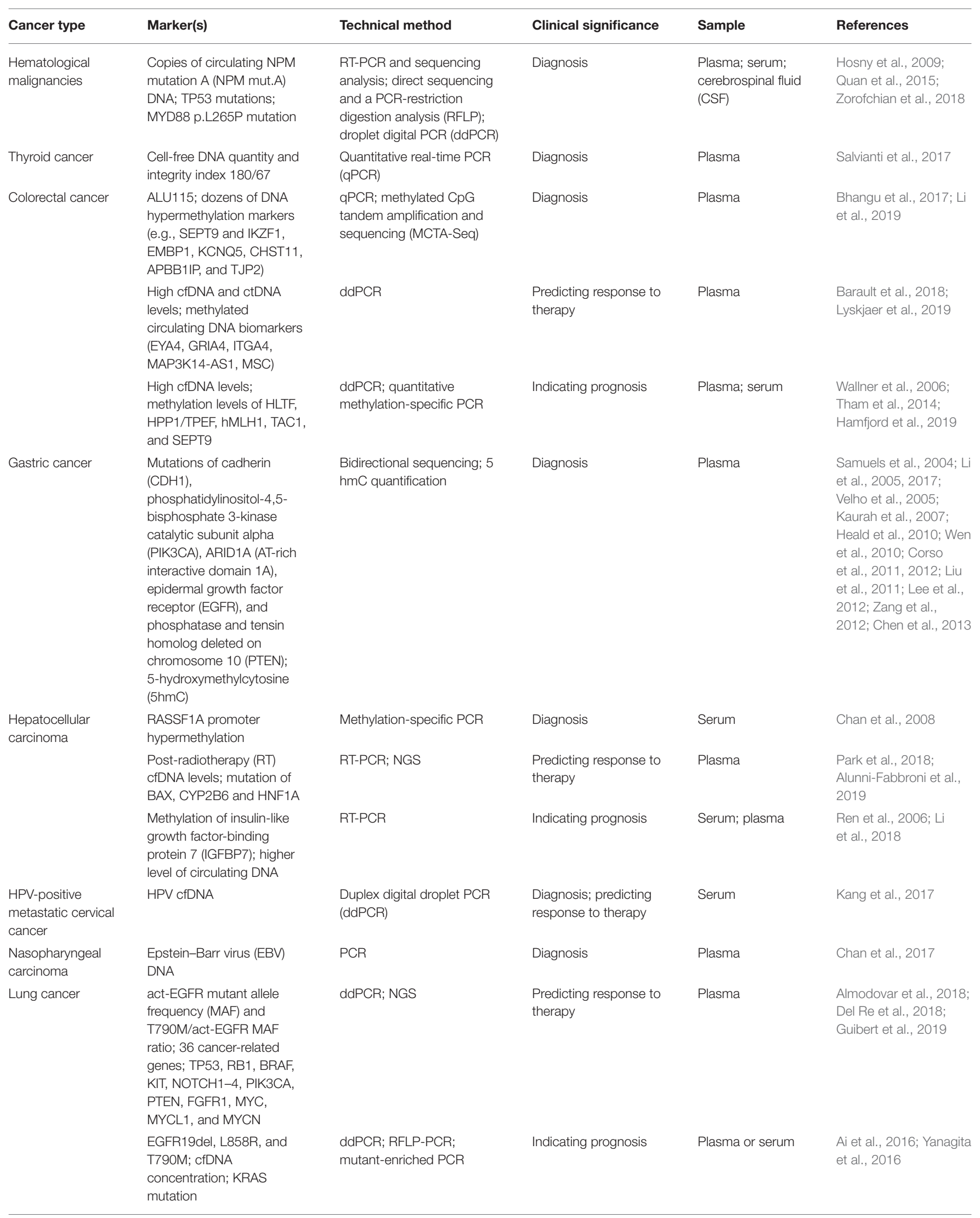


TABLE 2 | Continued

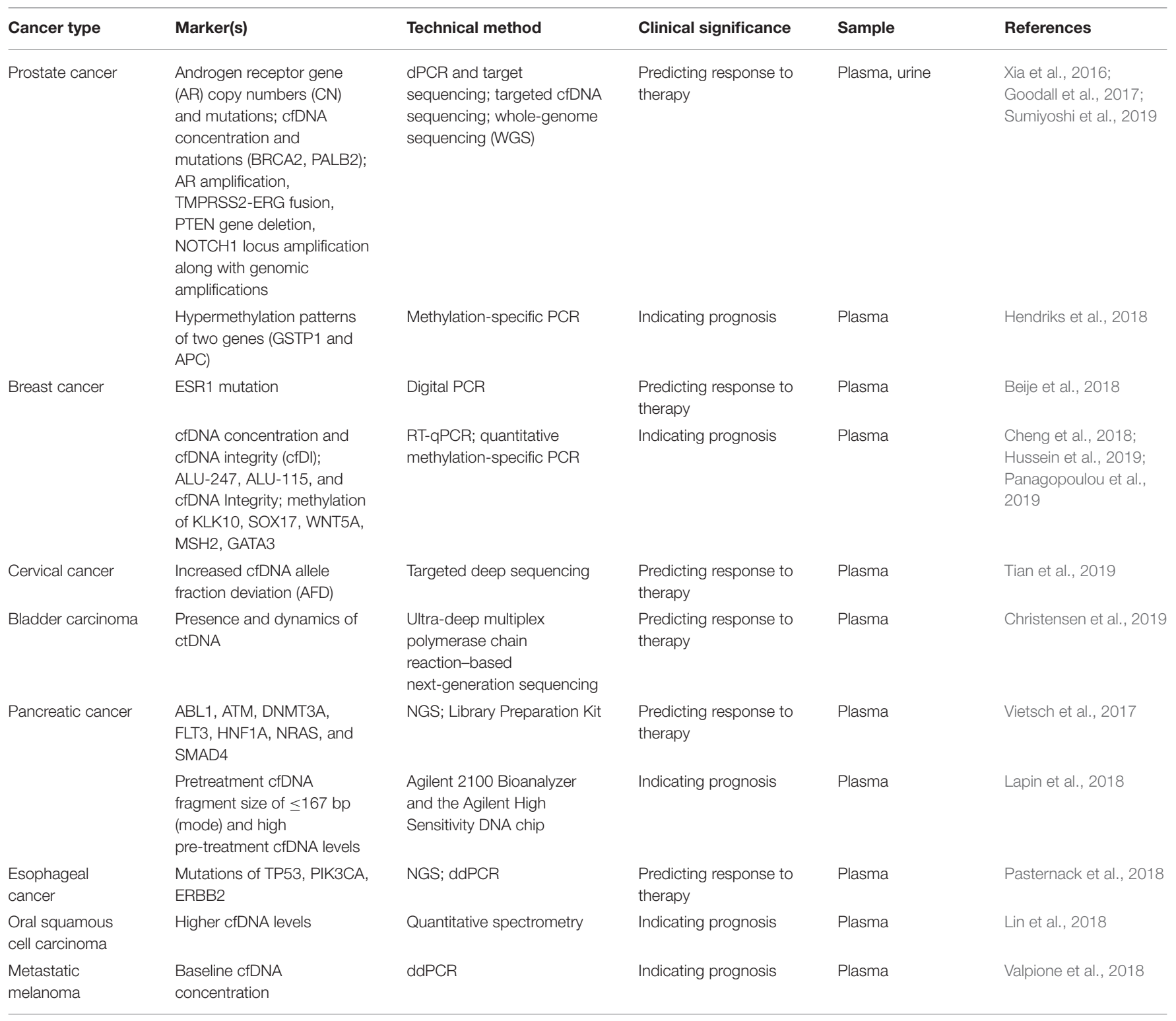

(Wang et al., 2004). In the study of Anker et al. (1997), a high (86\%) KRAS mutation in codon 12 was found in tumor tissue and blood. Thierry et al. (2014) reported an even higher (96\%) mutation of KRAS in codons 12 and 13 in tumor tissues and blood, and the mutation of BRAF (V600E) reached 100\%. Bhangu et al. (2017) found that the level of ALU115 in cfDNA could be an indicator of colorectal cancer (CRC).

$\mathrm{Li}$ et al. adopted a fully methylated molecule algorithm with the methylated $\mathrm{CpG}$ tandem amplification and sequencing (MCTA-Seq) method, to examine the blood sample of patients with CRC $(n=147)$ and healthy individuals $(n=136)$, as well as cancer and adjacent noncancerous tissues $(n=66)$. They found that a number of biomarkers of DNA hypermethylation including the known (e.g., SEPT9 and IKZF1) and the novel (e.g. TJP2, EMBP1, APBB1IP, CHST11, and KCNQ5) genes were detected in cfDNA of CRC (Li et al., 2019).

\section{Gastric Cancer}

It was known that mutations in genes such as CDH1 (Kaurah et al., 2007; Corso et al., 2012; Chen et al., 2013), PIK3CA (Samuels et al., 2004; Li et al., 2005; Velho et al., 2005; Lee et al., 2012), ARID1A (AT-rich interactive domain 1A) (Zang et al., 2012), EGFR (Corso et al., 2011; Liu et al., 2011), and PTEN (Heald et al., 2010; Wen et al., 2010) existed in gastric cancer, providing potential circulating DNA for detection of gastric cancer. For example, a clinical correlation analysis of ctDNA in patients with gastric adenocarcinoma showed that PIK3CA is one of the most frequently affected character-altered 
alterations, which can help to indicate clinically relevant genomic data for clinical diagnosis and treatment (Maron et al., 2019). Li et al. (2017) reported that $5 \mathrm{hmC}$ of circulating cfDNA could specifically and sensitively separate gastric cancer patients from healthy subjects.

\section{Hepatocellular Carcinoma}

DNA methylation is involved in activating protooncogenes or inactivating tumor-suppressor genes. The study of Yeo et al. (2005) revealed that RASSF1A promoter hypermethylation in blood cfDNA is correlated with the size of hepatocellular carcinoma (HCC). Furthermore, patients with hypermethylated RASSF1A in cfDNA at the time of diagnosis or 1 year after tumor resection have shorter DFS (Chan et al., 2008). The detection of RASSF1A promoter methylation in cfDNA in the blood is $90 \%$ in HCC patients and only $10 \%$ in healthy subjects. The mean blood level of methylated RASSF1A in HCC patients is significantly higher than that in healthy individuals (Mohamed et al., 2012).

\section{Virus-associated Cancer}

cfDNA analysis has been used to screen diseases before clinical onset (Mao et al., 1994; Gormally et al., 2006; Phallen et al., 2017). cfDNA analysis has shown to be an effective way to screen the asymptomatic early-stage nasopharyngeal carcinoma caused by Epstein-Barr virus (EBV), as the viral cfDNA level is much higher than that of ctDNA. One study involved in screening of $>20,000$ asymptomatic subjects for EBV DNA in blood has led to the diagnosis of nasopharyngeal carcinoma in 34 individuals (Chan et al., 2017). Identification of these early diagnosed patients improved the 3-year progression-free survival (Chan et al., 2017). Circulating cfDNA of human papillomavirus (HPV) (HPV ccfDNA) may be used as a unique tumor biomarker for HPVassociated malignancies, including cervical cancer (Kang et al., 2017).

\section{cfDNA IN MONITORING DISEASE PROGRESSION AND PREDICTING TREATMENT RESPONSE IN CANCERS}

Since access to longitudinal tumor tissues are limited, some studies chose to focus on the characterization of cfDNA for rapid, noninvasive monitoring for disease progression, treatment response, and disease relapse.

\section{Hepatocellular Carcinoma}

cfDNA is used as a prognostic biomarker in patients with advanced HCC. Park et al. examined the clinical significance of cfDNA in patients with HCC treated with radiotherapy (RT). They found that the level of post-RT cfDNA was negatively correlated with treatment outcome, indicating the potential of using post-RT cfDNA level as a predictor of treatment response and local control (LC) (Park et al., 2018). Alunni-Fabbroni et al. investigated the use of cfDNA and ctDNA in HCC patients to assess therapeutic response and clinical outcome. The level of cfDNA was shown to have a significant correlation with tumor metastases and patient survival. In addition, a dynamic study on cfDNA uncovered a trend of cfDNA level with the clinical history of patients, suggesting its usefulness as a biomarker for monitoring treatment response. Twenty-eight variants were identified in different combinations at different time points using NGS-based analysis on ctDNA. Among these variants, BAX, CYP2B6, and HNF1A genes showed the highest frequency of mutation and a significant association with the clinicopathological characteristics of patients, indicating their possible roles as driver genes in the clinical setting (AlunniFabbroni et al., 2019). The relationship between the level of blood cfDNA and clinicopathological characteristics was investigated in other studies. It was found that HCC patients with a larger tumor size $(\geq 5 \mathrm{~cm})$ or vascular invasion often showed higher levels of blood cfDNA (Iizuka et al., 2006; Huang et al., 2012). Huang et al. (2012) investigated the dynamic change of the level of blood cfDNA in patients with stage I-IV HCC and found that the level of cfDNA decreases after removal of tumors.

\section{Lung Cancer}

The correlation between osimertinib treatment outcome and activating EGFR (act-EGFR) mutations and T790M in cfDNA was evaluated in patients with advanced non-small cell lung cancer (NSCLC). Thirty-four patients with NSCLC resistant to first- and second-generation EGFR-TKIs, who are positive for both act-EGFR and T790M in cfDNA at the time of progression, were enrolled in this study. Blood samples were collected at baseline and 3 months after osimertinib treatment. cfDNA was analyzed by droplet digital PCR, and the results were expressed as mutant allele frequency (MAF). At baseline, the MAF of act-EGFR was significantly higher than that of T790M $(p<$ 0.0001). The act-EGFR MAF and ratio of T790M/act-EGFR MAF was significantly correlated with disease response $(p=$ 0.02). The cutoff value of act-EGFR MAF and T790M/act-EGFR ratio was found to be $2.6 \%$ and 0.22 , respectively. The PFS of patients with act-EGFR MAF of $>2.6$ and $<2.6 \%$, was 10 months vs. not reached, respectively ( $p=0.03$ ), whereas patients with T790M/act-EGFR $\leq 0.22$ had poorer PFS than those $>0.22$ (6 months vs. not reached, respectively, $p=0.01$ ). act-EGFR MAF and T790M/act-EGFR MAF ratio are potential indicators of outcome in patients treated with osimertinib. The amount of activating EGFR mutations in circulating cfDNA is an indicator for monitoring osimertinib response (Del Re et al., 2018).

Mutation of tumor genes can be indicators of treatment response to immune checkpoint inhibitors (ICI) (Yuan et al., 2019). The study of Guibert et al. showed that sequencing of blood cfDNA can predict response to PD1 inhibitors in advanced NSCLC. The presence of a PTEN or STK11 mutation was correlated with early progression, while transversion mutations (Tv) in KRAS and TP53 predicted better outcomes. Patients with a low immune score (driver gene and/or PTEN or STK11 mutation and/or without KRAS or TP53 Tv) have a poor outcome with a median PFS of 2 months, compared with patients who have a high immune score (no driver gene, no PTEN or STK11, and with KRAS or TP53 Tv) and have a median PFS of 14 months ( $p$ $=0.0001, \mathrm{HR}=2.96)$. Another study showed that the change of allele fraction (AF) of ctDNA is correlated with clinical outcomes in 65 specimens, where the PFS is 14 months if AF decreases vs. 2 months if AF increases ( $p<0.0001)$ (Guibert et al., 2019). 
Almodovar et al. (2018) demonstrated that longitudinal cfDNA analysis in patients with small cell lung cancer (SCLC) can reveal insights into treatment efficacy and disease relapse.

\section{Colorectal Cancer}

Lyskjær et al. suggested that the level of cfDNA and ctDNA is correlated with the outcome of FOLFIRI treatment in metastatic colorectal cancer (mCRC). In their study, 24 patients with mCRC were enrolled and treated with FOLFIRI-based therapy. Blood was sampled before treatment, at days 7, 14, 21, and 60 after treatment and at progression, and the level of cfDNA and ctDNA was analyzed. Patients with a high level of pretreatment ctDNA or cfDNA ( $\geq 75$ th percentile) had significantly shorter PFS than those with a low level of ctDNA or cfDNA. Despite an overall decline in ctDNA level from pretreatment to first CT scan, 7 patients were identified with temporary increases in ctDNA and these patients had shorter PFS and OS, which was coincident with growth of drug-resistant cells. This study indicated that increased level of ctDNA in the first cycle of FOLFIRI treatment was an indicator of progressive disease and poor survival. Therefore, monitoring the level of ctDNA as early as 1 week after treatment is important for early detection of treatment failure (Lyskjaer et al., 2019).

Zitt et al. (2008) reported that the blood level of cfDNA decreased in patients who responded to chemoradiotherapy (responders, stage I-II), while the blood level of cfDNA increased in the nonresponders. The integrity index of cfDNA was lower after chemoradiotherapy (CRT) in responders when compared to nonresponders. In general, patients with CRC have 10 times higher integrity index than healthy individuals (Agostini et al., 2011). Sun et al. (2014) observed that the incidence of KRAS mutation at codon 12 in cfDNA decreased in responders.

Methylation test in liquid biopsy can be used in the absence of specific mutations of patients to monitor dynamic tumor burden. The selected biomarkers allowed monitoring tumor burden under different treatment regimens. Methylation test might be used to assess pharmacodynamics in clinical trials or in complementing conventional imaging analysis. Barault et al. (2018) reported that dynamics of methylation biomarkers was correlated with subjective tumor response and progression-free survival in patients with metastatic colorectal cancer.

\section{Prostate Cancer}

cfDNA analysis can be used as a useful tool for precision medicine in castration-resistant prostate cancer (CRpC). Sumiyoshi et al. (2019) analyzed the cfDNA from 41 patients with CRpC. Most AR aberrations at baseline diminished with effective treatments, whereas AR amplification or mutations emerged in some patients with disease progression.

Goodall et al. reported that cfDNA analysis could guide the treatment of using poly(ADP)-ribose polymerase (PARP) inhibitor olaparib in metastatic prostate cancer (mPC). A decrease in blood level of cfDNA is correlated with the treatment outcome of PARP inhibitor olaparib in the Phase II Trial of Olaparib in Patients with Advanced Castration Resistant Prostate Cancer (Goodall et al., 2017). Briefly, somatic mutations of DNA repair were detectable in cfDNA in tumor tissues. The allele frequency of somatic mutations decreased selectively in responding patients (Chi-squared $p<0.001$ ). Multiple subclonal aberrations revert somatic and germline mutations of DNA repair (BRCA2, PALB2) following response to olaparib treatment as disease progressed (Goodall et al., 2017).

To evaluate the tumor DNA fraction in urine cfDNA, Xia et al. developed an algorithm of Urine Genomic Abnormality (UGA) score which summed up the top 10 most significant segments with copy number changes. The UGA score is correlated with tumor burden, and the change in UGA score after stage-specific therapy reflected the status of disease progression and overall survival. The study demonstrated the potential clinical use of urine cfDNA in predicting treatment response and monitoring disease progression (Xia et al., 2016).

\section{Breast Cancer}

Monitoring gene mutations is important in clinics. Notably, ESR1 mutation is detected at a high frequency in cfDNA of ER-positive metastatic breast cancer (MBC) and rarely found at the early-stage cancer. ESR1 mutation is enriched at disease progression, suggesting a role of ESR1 in MBC (Beije et al., 2018). The presence of ESR1 mutation indicates the development of endocrine resistance, especially resistant to aromatase inhibitors (Spoerke et al., 2016). Beije et al. (2018) suggested that ESR1 mutation is more prevalent in tumor progression $(42 \%)$ than before progression $(11 \%)(P=0.04)$.

\section{Cervical Cancer}

Tian et al. applied blood cfDNA analysis to evaluate the dynamic mutational change in 48 cancer driver genes in cervical cancer patients. They found that different treatments, including radiotherapy $(n=14)$, chemotherapy $(n=22)$, and surgery $(n$ $=15$ ), resulted in a significant decrease in the value of allele fraction deviation (AFD) (Wilcoxon, $p=0.029$ ). The decrease of $\mathrm{cfDNA}$ AFD value was associated with reduced size of tumor in most patients. Progressive disease (metastasis) was detected in a subgroup of patients whose cfDNA AFD value did not reflect a reduction in tumor size. Also, a low AFD value at diagnosis followed by a later increased AFD value predicted disease relapse (Tian et al., 2019).

HPV ccfDNA could be used to select patients for HPV-typespecific T-cell-based immunotherapies. It might also have a value for evaluating antitumor activity of therapeutic drugs and longterm follow-up in patients with cervical cancer. Kang et al. proposed an approach to genotype and quantify HPV-circulating DNA in patients with HPV16- or HPV18-positive metastatic cervical cancer for potential disease monitoring and treatment decision making. In this retrospective study, HPV ccfDNA was detected in 100\% (19 of 19) patients with HPV-positive metastatic cervical cancer but not in any of the 45 healthy blood donors. The HPV genotype harbored in the patients' tumors was correctly identified in $100 \%$ ( 87 of 87 ) of serial blood samples of nine patients who received TIL immunotherapy. In three patients who experienced objective cancer regression after TIL treatment, a transient HPV ccfDNA peak was observed 2-3 days after TIL infusion. Moreover, persistent clearance of HPV ccfDNA was 
found in two patients who experienced complete response (CR) after TIL immunotherapy (Kang et al., 2017).

\section{Bladder Carcinoma}

Using Ultra-Deep Sequencing of Plasma Cell-Free DNA, Emil Christensen and his group evaluated early metastatic relapse and examined treatment efficacy of urothelial bladder carcinoma. They found that ctDNA positivity before or in the course of treatment indicated high-risk patients. The dynamic change of ctDNA is correlated with tumor recurrence (Christensen et al., 2019).

\section{Pancreatic Cancer}

Analysis of cfDNA can be applied to evaluate the mutational makeup of cancer lesions and monitor cancer progression at the molecular level with no need of invasively acquired tissues from primary or metastatic lesions. Vietsch et al. showed that incorporation of cfDNA analysis provides crucial insights into the molecular change of progression of colon and pancreatic cancer. They revealed that cfDNA collected at the time of progression harbored 3-5 new mutations not detected in cfDNA collected at the earlier time points (Vietsch et al., 2017).

\section{Esophageal Cancer}

Pasternack et al. (2018) found that detection of somatically altered cfDNA in patients with esophageal carcinoma in early stage is associated with postsurgical tumor recurrence.

\section{cfDNA AS A PROGNOSTIC BIOMARKER FOR CANCER}

cfDNA is attracting attention as a novel biomarker for predicting outcome in oncology and is able to predict overall survival in cancer patients.

\section{Breast Cancer}

Panagopoulou et al. revealed that elevated concentrations of blood cfDNA are correlated with nonresponse to pharmacotherapy, shorter progression-free survival (PFS), and increased incidence of death in metastatic breast cancer (MBC). The methylation of WNT5A was significantly correlated with large tumor size, poor prognosis, and advanced-stage disease with short overall survival in MBC patients (Panagopoulou et al., 2019). Hussein et al. (2019) suggested that both plasma ALU-247 and ALU-115 repeats were preoperative prognostic biomarkers for breast cancer. Schiavon et al. (2015) showed that metastatic breast cancer patients with ESR1 mutations in their ctDNA had substantially shorter PFS on subsequent aromatase inhibitor-based therapy. Cheng et al. (2018) found that the integrity and blood level of cfDNA can serve as attractive and independent prognostic biomarkers for MBC patients at baseline and in the course of systematic therapy. The cfDNA mutation has also been evaluated in MBC. Chandarlapaty et al. (2016) showed that ESR1 mutation was associated with poor outcome in patients with metastatic breast cancer who were previously treated with an aromatase inhibitor.

\section{Lung Cancer}

A prospective phase II trial evaluated cfDNA in patients with EGFR-mutant NSCLC treated with erlotinib until progression. Results indicated that the level of cfDNA is correlated with PFS. High level of cfDNA was defined as $>55$ EGFR mutation copies/mL compared with low level of cfDNA, which is $<55$ EGFR-mutant copies/mL. The median PFS of patients with highlevel cfDNA ( $n=18$ ) was 9.3 months (95\% CI, $6.3-14.8)$ vs. 14.0 months (95\% CI, 9.2-20.1) for patients with low-level cfDNA ( $n$ $=41 ; P=0.08$ ) (Yanagita et al., 2016). Circulating cfDNA can be a predictive and prognostic biomarker in NSCLC. Several studies have assessed the predictive and prognostic value of cfDNA in NSCLC. A meta-analysis result demonstrated that NSCLC patients with high level of cfDNA were significantly associated with poor PFS. In addition, NSCLC patients who harbored EGFR mutation in cfDNA had a greater chance of response to EGFRTKIs (Ai et al., 2016).

\section{Hepatocellular Carcinoma}

Li et al. reported that cfDNA of methylated insulin-like growth factor-binding protein 7 (IGFBP7) was associated with overall survival and early tumor recurrence. Therefore, IGFBP7 could be an independent prognostic factor in hepatitis B virus-associated hepatocellular carcinoma after hepatectomy (Li et al., 2018). Ren et al. investigated the association between blood cfDNA level and overall survival and disease-free survival in patients with stage IIV HCC. They found that a high level of cfDNA was associated with poor overall survival (Ren et al., 2006).

\section{Pancreatic Cancer}

It was suggested that ctDNAs are shorter than cfDNA fragments originated from nonmalignant cells. Lapin et al. evaluated whether the size of cfDNA fragment and level of cfDNA had prognostic value in patients with advanced pancreatic cancer. Results indicated that both high cfDNA level and a cfDNA fragment size of $\leq 167 \mathrm{bp}$ before treatment were associated with shorter PFS and OS (Lapin et al., 2018). Chen et al. suggested that cfDNA was a prognostic factor for OS and PFS in patients with pancreatic cancer. The presence of ctDNA, high level of cfDNA, mutation including Kras, ERBB2-exon17, and KrasG12V; and hypermethylation were associated with poor survival in pancreatic cancer (Chen et al., 2018).

\section{Colorectal Cancer}

The analysis of cfDNA before surgery can indicate prognosis, and analysis of cfDNA after surgery can predict recurrence. A high level of blood cfDNA in the pretreatment phase is significantly correlated with poor survival (Schwarzenbach et al., 2008; Spindler et al., 2015). A prospective multicenter phase III trial indicated that the level of cfDNA can be a prognostic biomarker for oxaliplatin-based chemotherapy in metastatic colorectal cancer. A high level of cfDNA was associated with poor outcome. The median PFS is 7.7 months for the cfDNA level above the upper limit of normal (ULN) and 8.3 months for the cfDNA level below ULN. The median OS is 16.6 months for a cfDNA level above ULN and 25.9 months for a cfDNA level below ULN (Hamfjord et al., 2019). Patients with locally advanced-stage 
III-IV rectal cancer who had a high baseline cfDNA level showed short DFS (Schou et al., 2018).

The presence of methylation in HLTF and HPP1 genes in cfDNA in patients with stage I-IV colorectal cancer was associated with a poor OS (Wallner et al., 2006). Promoter methylation of three genes (HPP1, HLTF, and hMLH1) in blood cfDNA was positively correlated with tumor size. Also, methylation of HLTF and HPP1 genes was detected more frequently in metastatic CRC patients and in patients with high tumor stage (Philipp et al., 2012). The presence of a high level of TAC1 methylation 6-12 months after diagnosis was associated with early recurrence (Tham et al., 2014). The methylated status of the APC gene in cfDNA was associated with higher stage and older age. Moreover, patients with the unmethylated promoter of APC or RASSF1A genes showed better OS than patients with promoter hypermethylation (Matthaios et al., 2016).

\section{Oral Squamous Cell Carcinoma}

Lin et al. evaluated plasma cfDNA in 121 patients with oral squamous cell carcinoma (OSCC) and 50 matched controls using quantitative spectrometry. Results indicated that blood cfDNA was significantly increased in patients with OSCC compared to controls. The high level of blood cfDNA was correlated with large tumor size, cervical lymph node metastasis, and late stage. High level of blood cfDNA was associated with a poor prognosis of OSCC (Lin et al., 2018).

\section{Prostate Cancer}

Epigenetic biomarkers in circulating cfDNA can predict survival of castration-resistant prostate cancer patients. A high level of cfDNA and methylated GSTP1 and APC was observed in CRPC patients compared to healthy subjects. Moreover, the baseline level of cfDNA and methylated APC and GSTP1 before treatment can predict overall survival (Hendriks et al., 2018).

\section{Melanoma}

Valpione et al. (2018) revealed that the blood total cfDNA is a surrogate biomarker for tumor burden and can predict overall survival in patients with metastatic melanoma.

\section{CONCLUSION}

Analysis of cfDNA in liquid biopsy is a minimally invasive, lowcost, and promising alternative to tumor biopsy. Liquid biopsy

\section{REFERENCES}

Agostini, M., Pucciarelli, S., Enzo, M. V., Del Bianco, P., Briarava, M., Bedin, C., et al. (2011). Circulating cell-free DNA: a promising marker of pathologic tumor response in rectal cancer patients receiving preoperative chemoradiotherapy. Ann. Surg. Oncol. 18, 2461-2468. doi: 10.1245/s10434-011-1638-y

Ai, B., Liu, H., Huang, Y., and Peng, P. (2016). Circulating cell-free DNA as a prognostic and predictive biomarker in non-small cell lung cancer. Oncotarget. 7, 44583-44595. doi: 10.18632/oncotarget.10069

Almodovar, K., Iams, W. T., Meador, C. B., Zhao, Z., York, S., Horn, L., et al. (2018). Longitudinal cell-free DNA analysis in patients with small cell lung based on cfDNA can not only detect cancer recurrence more quickly than the current radiological imaging technology but also provide insights on the molecular evolution of minimal residual disease $(\mathrm{MRD})$ in tumor progression through molecular characterization of cfDNA, which is of great significance for the prevention and treatment of tumor recurrence. The most common body fluid is blood. In addition, different body fluids will be selected for different detection targets. For example, saliva is often used in the detection of head and neck tumor, and cerebrospinal fluid is applied in the diagnosis of tumors of the central nervous system, urine in the case of urinary tract cancers, and pleural effusion for respiratory tract cancers. However, due to the very low concentration of cfDNA in blood or other samples, it has high requirements for sensitivity and detection limit of the detection method. The gold standard of cfDNA analysis, including quantitative PCR (qPCR) and digital $\mathrm{PCR}$, is becoming mature. In recent years, the development of whole-genome sequencing and novel PCR-free biosensing approaches have also made some breakthroughs. In this article, we reviewed studies exploring cfDNA for diagnostic, therapeutic, and prognostic evaluation in various types of cancers. This study supports the idea that cfDNA analysis for cancer represents a potential research area and will have wide application in clinics.

\section{AUTHOR CONTRIBUTIONS}

Y-yY, Q-rG, and J-yZ conceived the review. Y-yY, F-hW, and $\mathrm{Z}$-yZ searched the literature and drafted the manuscript. RA, $\mathrm{H}-\mathrm{yZ}$, and $\mathrm{W}-\mathrm{mZ}$ critically appraised the literature. HY and $\mathrm{J}-\mathrm{qL}$ edited the manuscript. All authors approved the final version of the manuscript.

\section{FUNDING}

This work is supported by the Finance Science and Technology project of Hainan province (ZDYF2020137), the Natural Science Foundation of Guangdong Province (2020A1515010605), the National Natural Science Foundation of China (81902152 and 81773888), the Social Development Foundation of Shanxi Province (201903D321021), and the Fund of Shanxi Province Higher Education Technology Innovation Project (2019L0753). cancer reveals dynamic insights into treatment efficacy and disease relapse. $J$. Thorac. Oncol. 13, 112-123. doi: 10.1016/j.jtho.2017.09.1951

Alunni-Fabbroni, M., Ronsch, K., Huber, T., Cyran, C. C., Seidensticker, M., Mayerle, J., et al. (2019). Circulating DNA as prognostic biomarker in patients with advanced hepatocellular carcinoma: a translational exploratory study from the SORAMIC trial. J. Transl. Med. 17:328. doi: 10.1186/s12967-019-2079-9

Anker, P., Lefort, F., Vasioukhin, V., Lyautey, J., Lederrey, C., Chen, X. Q., et al. (1997). K-ras mutations are found in DNA extracted from the plasma of patients with colorectal cancer. Gastroenterology. 112, 1114-1120. doi: 10.1016/s0016-5085(97)70121-5

Barault, L., Amatu, A., Siravegna, G., Ponzetti, A., Moran, S., Cassingena, A., et al. (2018). Discovery of methylated circulating DNA biomarkers for 
comprehensive non-invasive monitoring of treatment response in metastatic colorectal cancer. Gut. 67, 1995-2005. doi: 10.1136/gutjnl-2016-313372

Beije, N., Sieuwerts, A. M., Kraan, J., Van, N. M., Onstenk, W., Vitale, S. R., et al. (2018). Estrogen receptor mutations and splice variants determined in liquid biopsies from metastatic breast cancer patients. Mol. Oncol. 12, 48-57. doi: 10.1002/1878-0261.12147

Beranek, M., Fiala, Z., Kremlacek, J., Andrys, C., Krejsek, J., Hamakova, K., et al. (2017). Changes in circulating cell-free DNA and nucleosomes in patients with exacerbated psoriasis. Arch. Dermatol. Res. 309, 815-821. doi: 10.1007/s00403-017-1785-5

Bettegowda, C., Sausen, M., Leary, R. J., Kinde, I., Wang, Y., Agrawal, N., et al. (2014). Detection of circulating tumor DNA in earlyand late-stage human malignancies. Sci. Transl. Med. 6:224ra24. doi: 10.1158/1538-7445.AM2014-5606

Bhangu, J. S., Taghizadeh, H., Braunschmid, T., Bachleitner-Hofmann, T., and Mannhalter, C. (2017). Circulating cell-free DNA in plasma of colorectal cancer patients - A potential biomarker for tumor burden. Surg. Oncol. 26, 395-401. doi: 10.1016/j.suronc.2017.08.001

Bianchi, D. W., and Chiu, R. W. K. (2018). Sequencing of circulating cell-free DNA during pregnancy. N. Engl. J. Med. 379, 464-473. doi: 10.1056/NEJMra1705345

Chan, K. C., Lai, P. B., Mok, T. S., Chan, H. L., Ding, C., Yeung, S. W., et al. (2008). Quantitative analysis of circulating methylated DNA as a biomarker for hepatocellular carcinoma. Clin. Chem. 54, 1528-1536. doi: 10.1373/clinchem.2008.104653

Chan, K. C. A., Woo, J. K. S., King, A., Zee, B. C. Y., Lam, W. K. J., Chan, S. L., et al. (2017). Analysis of plasma Epstein-Barr virus DNA to screen for nasopharyngeal cancer. N. Engl. J. Med. 377, 513-522. doi: 10.1056/NEJMoa1701717

Chandarlapaty, S., Chen, D., He, W., Sung, P., Samoila, A., You, D., et al. (2016). Prevalence of ESR1 mutations in cell-free DNA and outcomes in metastatic breast cancer: a secondary analysis of the BOLERO-2 clinical trial. JAMA Oncol. 2, 1310-1315. doi: 10.1001/jamaoncol.2016.1279

Chen, L., Zhang, Y., Cheng, Y., Zhang, D., Zhu, S., and Ma, X. (2018). Prognostic value of circulating cell-free DNA in patients with pancreatic cancer: A a systemic review and meta-analysis. Gene. 679, 328-334. doi: 10.1016/j.gene.2018.09.029

Chen, Q. H., Deng, W., Li, X. W., Liu, X. F., Wang, J. M., Wang, L. F., et al. (2013). Novel CDH1 germline mutations identified in Chinese gastric cancer patients. World J. Gastroenterol. 19, 909-916. doi: 10.3748/wjg.v19.i6.909

Cheng, J., Holland-Letz, T., Wallwiener, M., Surowy, H., Cuk, K., Schott, S., et al. (2018). Circulating free DNA integrity and concentration as independent prognostic markers in metastatic breast cancer. Breast Cancer Res. Treat. 169, 69-82. doi: 10.1007/s10549-018-4666-5

Christensen, E., Birkenkamp-Demtroder, K., Sethi, H., Shchegrova, S., Salari, R., Nordentoft, I., et al. (2019). Early detection of metastatic relapse and monitoring of therapeutic efficacy by ultra-deep sequencing of plasma cellfree DNA in patients with urothelial bladder carcinoma. J. Clin. Oncol. 37, 1547-1557. doi: 10.1158/1538-7445.SABCS18-913

Corso, G., Marrelli, D., Pascale, V., Vindigni, C., and Roviello, F. (2012). Frequency of $\mathrm{CDH} 1$ germline mutations in gastric carcinoma coming from high- and lowrisk areas: metanalysis and systematic review of the literature. BMC Cancer. 12:8. doi: 10.1186/1471-2407-12-8

Corso, G., Velho, S., Paredes, J., Pedrazzani, C., Martins, D., Milanezi, F., et al. (2011). Oncogenic mutations in gastric cancer with microsatellite instability. Eur. J. Cancer. 47, 443-451. doi: 10.1016/j.ejca.2010.09.008

Del Re, M., Bordi, P., Rofi, E., Restante, G., Valleggi, S., Minari, R., et al. (2018). The amount of activating EGFR mutations in circulating cell-free DNA is a marker to monitor osimertinib response. Br. J. Cancer. 119, 1252-1258. doi: 10.1038/s41416-018-0238-Z

Diehl, F., Schmidt, K., Choti, M. A., Romans, K., Goodman, S., Li, M., et al. (2008). Circulating mutant DNA to assess tumor dynamics. Nat. Med. 14, 985-990. doi: $10.1038 / \mathrm{nm} .1789$

Dunaeva, M., Derksen, M., and Pruijn, G. J. M. (2018). LINE-1 hypermethylation in serum cell-free DNA of relapsing remitting multiple sclerosis patients. Mol. Neurobiol. 55, 4681-4688. doi: 10.1007/s12035-017-0679-z

Duvvuri, B., and Lood, C. (2019). Cell-free DNA as a biomarker in autoimmune rheumatic diseases. Front. Immunol. 10:502. doi: 10.3389/fimmu.2019. 00502
Esposito, A., Criscitiello, C., Trapani, D., and Curigliano, G. (2017). The emerging role of "liquid biopsies," circulating tumor cells, and circulating cell-free tumor DNA in lung cancer diagnosis and identification of resistance mutations. Curr. Oncol. Rep. 19, 1. doi: 10.1007/s11912-017-0564-y

Fares, J., Fares, M. Y., Khachfe, H. H., Salhab, H. A., and Fares, Y. (2020). Molecular principles of metastasis: a hallmark of cancer revisited. Signal Transduct. Target. Ther. 5:28. doi: 10.1038/s41392-020-0134-x

Fontanilles, M., Marguet, F., Bohers, E., Viailly, P. J., Dubois, S., Bertrand, P., et al. (2017). Non-invasive detection of somatic mutations using next-generation sequencing in primary central nervous system lymphoma. Oncotarget. 8, 48157-48168. doi: 10.18632/oncotarget.18325

Fujiwara, K., Fujimoto, N., Tabata, M., Nishii, K., Matsuo, K., Hotta, K., et al. (2005). Identification of epigenetic aberrant promoter methylation in serum DNA is useful for early detection of lung cancer. Clin. Cancer Res. 11, 1219-1225. doi: 10.1016/S0140-6736(61)92729-5

Gala-Lopez, B. L., Neiman, D., Kin, T., O'Gorman, D., Pepper, A. R., Malcolm, A. J., et al. (2018). Beta cell death by cell-free DNA and outcome after clinical islet transplantation. Transplantation. 102, 978-985. doi: 10.1097/TP.0000000000002083

Gielis, E. M., Ledeganck, K. J., De Winter, B. Y., Del Favero, J., Bosmans, J. L., Claas, F. H., et al. (2015). Cell-free DNA: an upcoming biomarker in transplantation. Am. J. Transplant. 15, 2541-2551. doi: 10.1111/ajt.13387

Goodall, J., Mateo, J., Yuan, W., Mossop, H., Porta, N., Miranda, S., et al. (2017). Circulating cell-free DNA to guide prostate cancer treatment with PARP inhibition. Cancer Discov. 7, 1006-1017. doi: 10.1158/2159-8290.CD-17-0261

Gorges, T. M., Schiller, J., Schmitz, A., Schuetzmann, D., Schatz, C., Zollner, T. M., et al. (2012). Cancer therapy monitoring in xenografts by quantitative analysis of circulating tumor DNA. Biomarkers. 17, 498-506. doi: 10.3109/1354750X.2012.689133

Gormally, E., Vineis, P., Matullo, G., Veglia, F., Caboux, E., Le Roux, E., et al. (2006). TP53 and KRAS2 mutations in plasma DNA of healthy subjects and subsequent cancer occurrence: a prospective study. Cancer Res. 66, 6871-6876. doi: 10.1158/0008-5472.CAN-05-4556

Guibert, N., Jones, G., Beeler, J. F., Plagnol, V., Morris, C., Mourlanette, J., et al. (2019). Targeted sequencing of plasma cell-free DNA to predict response to PD1 inhibitors in advanced non-small cell lung cancer. Lung Cancer. 137, 1-6. doi: 10.1016/j.lungcan.2019.09.005

Haber, D. A., and Velculescu, V. E. (2014). Blood-based analyses of cancer: circulating tumor cells and circulating tumor DNA. Cancer Discov. 4, 650-661. doi: 10.1158/2159-8290.CD-13-1014

Hamfjord, J., Guren, T. K., Dajani, O., Johansen, J. S., Glimelius, B., Sorbye, H., et al. (2019). Total circulating cell-free DNA as a prognostic biomarker in metastatic colorectal cancer before first-line oxaliplatin-based chemotherapy. Ann. Oncol. 30, 1088-1095. doi: 10.1093/annonc/mdz139

Heald, B., Mester, J., Rybicki, L., Orloff, M. S., Burke, C. A., and Eng, C. (2010). Frequent gastrointestinal polyps and colorectal adenocarcinomas in a prospective series of PTEN mutation carriers. Gastroenterology. 139, 1927-1933. doi: 10.1053/j.gastro.2010.06.061

Hendriks, R. J., Dijkstra, S., Smit, F. P., Vandersmissen, J., Van de Voorde, H., Mulders, P. F. A., et al. (2018). Epigenetic markers in circulating cell-free DNA as prognostic markers for survival of castration-resistant prostate cancer patients. Prostate. 78, 336-342. doi: 10.1002/pros. 23477

Hiemcke-Jiwa, L. S., Leguit, R. J., Snijders, T. J., Bromberg, J. E. C., Nierkens, S., Jiwa, N. M., et al. (2019). MYD88 p.(L265P) detection on cell-free DNA in liquid biopsies of patients with primary central nervous system lymphoma. Br. J. Haematol. 185, 974-977. doi: 10.1111/bjh. 15674

Hohaus, S., Giachelia, M., Massini, G., Mansueto, G., Vannata, B., Bozzoli, V., et al. (2009). Cell-free circulating DNA in Hodgkin's and non-Hodgkin's lymphomas. Ann. Oncol. 20, 1408-1413. doi: 10.1093/annonc/mdp006

Hosny, G., Farahat, N., and Hainaut, P. (2009). TP53 mutations in circulating free DNA from Egyptian patients with non-Hodgkin's lymphoma. Cancer Lett. 275, 234-239. doi: 10.1016/j.canlet.2008.10.029

Huang, W., Yan, Y., Liu, Y., Lin, M., Ma, J., Zhang, W., et al. (2020). Exosomes with low miR-34c-3p expression promote invasion and migration of non-small cell lung cancer by upregulating integrin $\alpha 2 \beta 1$. Signal Transduct. Target. Ther. 5, 39. doi: $10.1038 / \mathrm{s} 41392-020-0133-y$ 
Huang, Z., Hua, D., Hu, Y., Cheng, Z., Zhou, X., Xie, Q., et al. (2012). Quantitation of plasma circulating DNA using quantitative PCR for the detection of hepatocellular carcinoma. Pathol. Oncol. Res. 18, 271-276. doi: 10.1007/s12253-011-9438-Z

Hudecova, I., and Chiu, R. W. (2017). Non-invasive prenatal diagnosis of thalassemias using maternal plasma cell free DNA. Best Pract. Res. Clin. Obstet. Gynaecol. 39, 63-73. doi: 10.1016/j.bpobgyn.2016.10.016

Hussein, N. A., Mohamed, S. N., and Ahmed, M. A. (2019). Plasma ALU-247, ALU-115, and cfDNA Integrity as Diagnostic and Prognostic Biomarkers for Breast Cancer. Appl. Biochem. Biotechnol. 187, 1028-1045. doi: 10.1007/s12010-018-2858-4

Hyett, J. A., Gardener, G., Stojilkovic-Mikic, T., Finning, K. M., Martin, P. G., Rodeck, C. H., et al. (2005). Reduction in diagnostic and therapeutic interventions by non-invasive determination of fetal sex in early pregnancy. Prenat. Diagn. 25, 1111-1116. doi: 10.1002/pd.1284

Iizuka, N., Sakaida, I., Moribe, T., Fujita, N., Miura, T., Stark, M., et al. (2006). Elevated levels of circulating cell-free DNA in the blood of patients with hepatitis C virus-associated hepatocellular carcinoma. Anticancer Res. 26, 4713-4719. doi: 10.1016/S0166-6851(00)00331-5

Kamat, A. A., Bischoff, F. Z., Dang, D., Baldwin, M. F., Han, L. Y., Lin, Y. G., et al. (2006). Circulating cell-free DNA: a novel biomarker for response to therapy in ovarian carcinoma. Cancer Biol. Ther. 5:1369-1374. doi: 10.4161/cbt.5.10.3240

Kang, Z., Stevanovic, S., Hinrichs, C. S., and Cao, L. (2017). Circulating cell-free DNA for metastatic cervical cancer detection, genotyping, and monitoring. Clin. Cancer Res. 23, 6856-6862. doi: 10.1158/1078-0432.CCR-17-1553

Kaurah, P., MacMillan, A., Boyd, N., Senz, J., De Luca, A., Chun, N., et al. (2007). Founder and recurrent $\mathrm{CDH} 1$ mutations in families with hereditary diffuse gastric cancer. JAMA. 297, 2360-2372. doi: 10.1001/jama.297.21.2360

Lapin, M., Oltedal, S., Tjensvoll, K., Buhl, T., Smaaland, R., Garresori, H., et al. (2018). Fragment size and level of cell-free DNA provide prognostic information in patients with advanced pancreatic cancer. J. Transl. Med. 16, 300. doi: 10.1186/s12967-018-1677-2

Lee, J., van Hummelen, P., Go, C., Palescandolo, E., Jang, J., Park, H. Y., et al. (2012). High-throughput mutation profiling identifies frequent somatic mutations in advanced gastric adenocarcinoma. PLoS One. 7:e38892. doi: 10.1371/journal.pone.0038892

Leon, S. A., Shapiro, B., Sklaroff, D. M., and Yaros, M. J. (1977). Free DNA in the serum of cancer patients and the effect of therapy. Cancer Res. 37, 646-650.

Li, F., Qiao, C. Y., Gao, S., Fan, Y. C., Chen, L. Y., and Wang, K. (2018). Circulating cell-free DNA of methylated insulin-like growth factorbinding protein 7 predicts a poor prognosis in hepatitis B virus-associated hepatocellular carcinoma after hepatectomy. Free Radic. Res. 52, 455-464. doi: 10.1080/10715762.2018.1443448

Li, J., Zhou, X., Liu, X., Ren, J., Wang, J., Wang, W., et al. (2019). Detection of colorectal cancer in circulating cell-free DNA by methylated CPG tandem amplification and sequencing. Clin. Chem. 65:916-926. doi: 10.1373/clinchem.2019.301804

Li, V. S., Wong, C. W., Chan, T. L., Chan, A. S., Zhao, W., Chu, K. M., et al. (2005). Mutations of PIK3CA in gastric adenocarcinoma. BMC Cancer. 5:29. doi: 10.1186/1471-2407-5-29

Li, W., Zhang, X., Lu, X., You, L., Song, Y., Luo, Z., et al. (2017). 5Hydroxymethylcytosine signatures in circulating cell-free DNA as diagnostic biomarkers for human cancers. Cell Res. 27, 1243-1257. doi: $10.1038 / \mathrm{cr} .2017 .121$

Lin, L. H., Chang, K. W., Kao, S. Y., Cheng, H. W., and Liu, C. J. (2018). Increased Plasma circulating cell-free DNA could be a potential marker for oral cancer. Int. J. Mol. Sci. 19, 3303. doi: 10.3390/ijms19113303

Liu, Z., Liu, L., Li, M., Wang, Z., Feng, L., Zhang, Q., et al. (2011). Epidermal growth factor receptor mutation in gastric cancer. Pathology. 43, 234-238. doi: 10.1097/PAT.0b013e328344e61b

Lo, Y. M., Corbetta, N., Chamberlain, P. F., Rai, V., Sargent, I. L., Redman, C. W., et al. (1997). Presence of fetal DNA in maternal plasma and serum. Lancet. 350, 485-487. doi: 10.1016/S0140-6736(97)02174-0

Lo, Y. M., Lun, F. M., Chan, K. C., Tsui, N. B., Chong, K. C., Lau, T. K., et al. (2007). Digital PCR for the molecular detection of fetal chromosomal aneuploidy. Proc. Natl. Acad. Sci. U. S. A. 104, 13116-13121. doi: 10.1073/pnas.0705765104

Lo, Y. M., Tein, M. S., Pang, C. C., Yeung, C. K., Tong, K. L., and Hjelm, N. M. (1998). Presence of donor-specific DNA in plasma of kidney and liver-transplant recipients. Lancet. 351, 1329-1330. doi: 10.1016/S0140-6736(05)79055-3

Lui, Y. Y., Chik, K. W., Chiu, R. W., Ho, C. Y., Lam, C. W., and Lo, Y. M. (2002). Predominant hematopoietic origin of cell-free DNA in plasma and serum after sex-mismatched bone marrow transplantation. Clin. Chem. 48, 421-427. doi: $10.1093 /$ clinchem/48.3.421

Lyskjaer, I., Kronborg, C. S., Rasmussen, M. H., Sorensen, B. S., Demuth, C., Rosenkilde, M., et al. (2019). Correlation between early dynamics in circulating tumour DNA and outcome from FOLFIRI treatment in metastatic colorectal cancer. Sci. Rep. 9, 11542. doi: 10.1038/s41598-019-47708-1

Malan, V., Bussieres, L., Winer, N., Jais, J. P., Baptiste, A., Le Lorc'h, M., et al. (2018). Effect of cell-free DNA screening vs direct invasive diagnosis on miscarriage rates in women with pregnancies at high risk of trisomy 21: a randomized clinical trial. JAMA. 320, 557-565. doi: 10.1001/jama.2018.9396

Mandel, P., and Metais, P. (1948). Nuclear acids in human blood plasma. C. R. Seances Soc. Biol. Fil. 142, 241-243.

Mao, L., Hruban, R. H., Boyle, J. O., Tockman, M., and Sidransky, D. (1994). Detection of oncogene mutations in sputum precedes diagnosis of lung cancer. Cancer Res. 54, 1634-1637. doi: 10.1016/0304-3835(94)90050-7

Maron, S. B., Chase, L. M., Lomnicki, S., Kochanny, S., Moore, K. L., Joshi, S. S., et al. (2019). Circulating Tumor DNA Sequencing Analysis of Gastroesophageal Adenocarcinoma. Clin. Cancer Res. 25, 7098-7112. doi: 10.1158/1078-0432.CCR-19-1704

Matthaios, D., Balgkouranidou, I., Karayiannakis, A., Bolanaki, H., Xenidis, N., Amarantidis, K., et al. (2016). Methylation status of the APC and RASSF1A promoter in cell-free circulating DNA and its prognostic role in patients with colorectal cancer. Oncol. Lett. 12, 748-756. doi: 10.3892/ol.2016.4649

Mithani, S. K., Smith, I. M., Zhou, S., Gray, A., Koch, W. M., Maitra, A., et al. (2007). Mitochondrial resequencing arrays detect tumor-specific mutations in salivary rinses of patients with head and neck cancer. Clin. Cancer Res. 13, 7335-7340. doi: 10.1158/1078-0432.CCR-07-0220

Mohamed, N. A., Swify, E. M., Amin, N. F., Soliman, M. M., Tag-Eldin, L. M., and Elsherbiny, N. M. (2012). Is serum level of methylated RASSF1A valuable in diagnosing hepatocellular carcinoma in patients with chronic viral hepatitis $\mathrm{C}$ ? Arab J. Gastroenterol. 13, 111-115. doi: 10.1016/j.ajg.2012.06.009

Mueller, S., Holdenrieder, S., Stieber, P., Haferlach, T., Schalhorn, A., Braess, J., et al. (2006). Early prediction of therapy response in patients with acute myeloid leukemia by nucleosomal DNA fragments. BMC Cancer. 6:143. doi: 10.1186/1471-2407-6-143

Nawroz, H., Koch, W., Anker, P., Stroun, M., and Sidransky, D. (1996). Microsatellite alterations in serum DNA of head and neck cancer patients. Nat. Med. 2, 1035-1037. doi: 10.1038/nm0996-1035

Panagopoulou, M., Karaglani, M., Balgkouranidou, I., Biziota, E., Koukaki, T., Karamitrousis, E., et al. (2019). Circulating cell-free DNA in breast cancer: size profiling, levels, and methylation patterns lead to prognostic and predictive classifiers. Oncogene. 38, 3387-3401. doi: 10.1038/s41388-01 8-0660-y

Park, S., Lee, E. J., Rim, C. H., and Seong, J. (2018). Plasma Cell-Free DNA as a Predictive Marker after radiotherapy for hepatocellular carcinoma. Yonsei Med. J. 59, 470-479. doi: 10.3349/ymj.2018.59.4.470

Parkinson, C. A., Gale, D., Piskorz, A. M., Biggs, H., Hodgkin, C., Addley, H., et al. (2016). Exploratory analysis of TP53 mutations in circulating tumour DNA as biomarkers of treatment response for patients with relapsed highgrade serous ovarian carcinoma: a retrospective study. PLoS Med. 13:e1002198. doi: 10.1371/journal.pmed.1002198

Pasternack, H., Fassunke, J., Plum, P. S., Chon, S. H., Hescheler, D. A., Gassa, A., et al. (2018). Somatic alterations in circulating cell-free DNA of oesophageal carcinoma patients during primary staging are indicative for post-surgical tumour recurrence. Sci. Rep. 8:14941. doi: 10.1038/s41598-01833027-4

Phallen, J., Sausen, M., Adleff, V., Leal, A., Hruban, C., White, J., et al. (2017). Direct detection of early-stage cancers using circulating tumor DNA. Sci. Transl. Med. 9, eaan2415. doi: 10.1126/scitranslmed.aan2415

Philipp, A. B., Stieber, P., Nagel, D., Neumann, J., Spelsberg, F., Jung, A., et al. (2012). Prognostic role of methylated free circulating DNA in colorectal cancer. Int. J. Cancer. 131, 2308-2319. doi: 10.1002/ijc.27505

Quan, J., Gao, Y. J., Yang, Z. L., Chen, H., Xian, J. R., Zhang, S. S., et al. (2015). Quantitative detection of circulating nucleophosmin mutations DNA in the 
plasma of patients with acute myeloid leukemia. Int. J. Med. Sci. 12:17-22. doi: 10.7150/ijms.10144

Raja, R., Kuziora, M., Brohawn, P. Z., Higgs, B. W., Gupta, A., Dennis, P. A., et al. (2018). Early reduction in ctDNA predicts survival in patients with lung and bladder cancer treated with durvalumab. Clin. Cancer Res. 24, 6212-6222. doi: 10.1158/1078-0432.CCR-18-0386

Ren, N., Ye, Q. H., Qin, L. X., Zhang, B. H., Liu, Y. K., and Tang, Z. Y. (2006). Circulating DNA level is negatively associated with the long-term survival of hepatocellular carcinoma patients. World J. Gastroenterol. 12, 3911-3914. doi: 10.3748/wjg.v12.i24.3911

Rhodes, C. H., Honsinger, C., and Sorenson, G. D. (1994). Detection of tumorderived DNA in cerebrospinal fluid. J. Neuropathol. Exp. Neurol. 53, 364-368. doi: 10.1097/00005072-199407000-00007

Salvianti, F., Giuliani, C., Petrone, L., Mancini, I., Vezzosi, V., Pupilli, C., et al. (2017). Integrity and quantity of total cell-free DNA in the diagnosis of thyroid cancer: correlation with cytological classification. Int. J. Mol. Sci. 18, 1350. doi: 10.3390/ijms18071350

Samuels, Y., Wang, Z., Bardelli, A., Silliman, N., Ptak, J., Szabo, S., et al. (2004). High frequency of mutations of the PIK3CA gene in human cancers. Science. 304:554. doi: 10.1126/science.1096502

Schiavon, G., Hrebien, S., Garcia-Murillas, I., Cutts, R. J., Pearson, A., Tarazona, N., et al. (2015). Analysis of ESR1 mutation in circulating tumor DNA demonstrates evolution during therapy for metastatic breast cancer. Sci. Transl. Med. 7:313ra182. doi: 10.1126/scitranslmed.aac7551

Schou, J. V., Larsen, F. O., Sorensen, B. S., Abrantes, R., Boysen, A. K., Johansen, J. S., et al. (2018). Circulating cell-free DNA as predictor of treatment failure after neoadjuvant chemo-radiotherapy before surgery in patients with locally advanced rectal cancer. Ann. Oncol. 29, 610-615. doi: 10.1093/annonc/mdx778

Schwarzenbach, H., Stoehlmacher, J., Pantel, K., and Goekkurt, E. (2008). Detection and monitoring of cell-free DNA in blood of patients with colorectal cancer. Ann. N. Y. Acad. Sci. 1137, 190-196. doi: 10.1196/annals.14 48.025

Shaw, J. A., Smith, B. M., Walsh, T., Johnson, S., Primrose, L., Slade, M. J., et al. (2000). Microsatellite alterations plasma DNA of primary breast cancer patients. Clin. Cancer Res. 6, 1119-1124. doi: 10.1159/000007270

Sherwood, K., and Weimer, E. T. (2018). Characteristics, properties, and potential applications of circulating cell-free dna in clinical diagnostics: a focus on transplantation. J. Immunol. Methods. 463, 27-38. doi: 10.1016/j.jim.2018.09.011

Shu, Y., Wu, X., Tong, X., Wang, X., Chang, Z., Mao, Y., et al. (2017). Circulating tumor DNA mutation profiling by targeted next generation sequencing provides guidance for personalized treatments in multiple cancer types. Sci. Rep. 7, 583. doi: 10.1038/s41598-017-00520-1

Sidransky, D., Von Eschenbach, A., Tsai, Y. C., Jones, P., Summerhayes, I., Marshall, F., et al. (1991). Identification of p53 gene mutations in bladder cancers and urine samples. Science. 252, 706-709. doi: 10.1126/science.2024123

Siravegna, G., Marsoni, S., Siena, S., and Bardelli, A. (2017). Integrating liquid biopsies into the management of cancer. Nat. Rev. Clin. Oncol. 14, 531-548. doi: 10.1038/nrclinonc.2017.14

Sorenson, G. D., Pribish, D. M., Valone, F. H., Memoli, V. A., Bzik, D. J., and Yao, S. L. (1994). Soluble normal and mutated DNA sequences from singlecopy genes in human blood. Cancer Epidemiol. Biomarkers Prev. 3, 67-71. doi: $10.1007 /$ BF00685912

Spindler, K. L., Pallisgaard, N., Andersen, R. F., Brandslund, I., and Jakobsen, A. (2015). Circulating free DNA as biomarker and source for mutation detection in metastatic colorectal cancer. PLoS One. 10:e0108247. doi: 10.1371/journal.pone.0108247

Spoerke, J. M., Gendreau, S., Walter, K., Qiu, J., Wilson, T. R., Savage, H., et al. (2016). Heterogeneity and clinical significance of ESR1 mutations in ERpositive metastatic breast cancer patients receiving fulvestrant. Nat. Commun. 7:11579. doi: 10.1038/ncomms11579

Sriram, K. B., Relan, V., Clarke, B. E., Duhig, E. E., Windsor, M. N., Matar, K. S., et al. (2012). Pleural fluid cell-free DNA integrity index to identify cytologically negative malignant pleural effusions including mesotheliomas. BMC Cancer. 12:428. doi: 10.1186/1471-2407-12-428

Sumiyoshi, T., Mizuno, K., Yamasaki, T., Miyazaki, Y., Makino, Y., Okasho, K., et al. (2019). Clinical utility of androgen receptor gene aberrations in circulating cell-free DNA as a biomarker for treatment of castration-resistant prostate cancer. Sci. Rep. 9:4030. doi: 10.1038/s41598-019-40719-y

Sun, K., Jiang, P., Chan, K. C., Wong, J., Cheng, Y. K., Liang, R. H., et al. (2015). Plasma DNA tissue mapping by genome-wide methylation sequencing for noninvasive prenatal, cancer, and transplantation assessments. Proc. Natl. Acad. Sci. U. S. A. 112, E5503-E5512. doi: 10.1073/pnas.1508736112

Sun, W., Sun, Y., Zhu, M., Wang, Z., Zhang, H., Xin, Y., et al. (2014). The role of plasma cell-free DNA detection in predicting preoperative chemoradiotherapy response in rectal cancer patients. Oncol. Rep. 31, 1466-1472. doi: 10.3892/or.2013.2949

Tham, C., Chew, M., Soong, R., Lim, J., Ang, M., Tang, C., et al. (2014). Postoperative serum methylation levels of TAC1 and SEPT9 are independent predictors of recurrence and survival of patients with colorectal cancer. Cancer. 120, 3131-3141. doi: 10.1002/cncr.28802

Thierry, A. R., Mouliere, F., El Messaoudi, S., Mollevi, C., Lopez-Crapez, E., Rolet, F., et al. (2014). Clinical validation of the detection of KRAS and BRAF mutations from circulating tumor DNA. Nat. Med. 20, 430-435. doi: $10.1038 / \mathrm{nm} .3511$

Tian, J., Geng, Y., Lv, D., Li, P., Cordova, M., Liao, Y., et al. (2019). Using plasma cell-free DNA to monitor the chemoradiotherapy course of cervical cancer. Int. J. Cancer. 145, 2547-2557. doi: 10.1002/ijc.32295

Tokuhisa, Y., Iizuka, N., Sakaida, I., Moribe, T., Fujita, N., Miura, T., et al. (2007). Circulating cell-free DNA as a predictive marker for distant metastasis of hepatitis C virus-related hepatocellular carcinoma. Br. J. Cancer. 97, 1399-1403. doi: $10.1038 /$ sj.bjc. 6604034

Valpione, S., Gremel, G., Mundra, P., Middlehurst, P., Galvani, E., Girotti, M. R., et al. (2018). Plasma total cell-free DNA (cfDNA) is a surrogate biomarker for tumour burden and a prognostic biomarker for survival in metastatic melanoma patients. Eur. J. Cancer. 88, 1-9. doi: 10.1016/j.ejca.2017.10.029

Vasioukhin, V., Anker, P., Maurice, P., Lyautey, J., Lederrey, C., and Stroun, M. (1994). Point mutations of the N-ras gene in the blood plasma DNA of patients with myelodysplastic syndrome or acute myelogenous leukaemia. $\mathrm{Br}$. J. Haematol. 86:774-779. doi: 10.1111/j.1365-2141.1994.tb04828.x

Velho, S., Oliveira, C., Ferreira, A., Ferreira, A. C., Suriano, G., Schwartz, S. Jr., et al. (2005). The prevalence of PIK3CA mutations in gastric and colon cancer. Eur. J. Cancer. 41:1649-1654. doi: 10.1016/j.ejca.2005.04.022

Vietsch, E. E., Graham, G. T., McCutcheon, J. N., Javaid, A., Giaccone, G., Marshall, J. L., et al. (2017). Circulating cell-free DNA mutation patterns in early and late stage colon and pancreatic cancer. Cancer Genet. 218--219, 39-50. doi: 10.1016/j.cancergen.2017.08.006

Vivanti, A. J., Costa, J. M., Rosefort, A., Kleinfinger, P., Lohmann, L., Cordier, A. G., et al. (2019). Optimal non-invasive diagnosis of fetal achondroplasia combining ultrasonography with circulating cell-free fetal DNA analysis. Ultrasound Obstet. Gynecol. 53, 87-94. doi: 10.1002/uog.19018

Wallner, M., Herbst, A., Behrens, A., Crispin, A., Stieber, P., Goke, B., et al. (2006) Methylation of serum DNA is an independent prognostic marker in colorectal cancer. Clin. Cancer Res. 12, 7347-7352. doi: 10.1158/1078-0432.CCR-06-1264

Wan, J. C. M., Massie, C., Garcia-Corbacho, J., Mouliere, F., Brenton, J. D., Caldas, C., et al. (2017). Liquid biopsies come of age: towards implementation of circulating tumour DNA. Nat. Rev. Cancer. 17, 223-238. doi: $10.1038 / \mathrm{nrc} .2017 .7$

Wang, J., and Xu, B. (2019). Targeted therapeutic options and future perspectives for HER2-positive breast cancer. Signal Transduct. Target. Ther. 4, 34. doi: 10.1038/s41392-019-0069-2

Wang, J. Y., Hsieh, J. S., Chang, M. Y., Huang, T. J., Chen, F. M., Cheng, T. L., et al. (2004). Molecular detection of APC, K- ras, and p53 mutations in the serum of colorectal cancer patients as circulating biomarkers. World J. Surg. 28, 721-726. doi: 10.1007/s00268-004-7366-8

Wang, Y., Fang, Z., Hong, M., Yang, D., and Xie, W. (2020). Long-noncoding RNAs (lncRNAs) in drug metabolism and disposition, implications in cancer chemoresistance. Acta Pharm. Sin. B. 10, 105-112. doi: 10.1016/j.apsb.2019.09.011

Wang, Y., Springer, S., Mulvey, C. L., Silliman, N., Schaefer, J., Sausen, M., et al. (2015). Detection of somatic mutations and HPV in the saliva and plasma of patients with head and neck squamous cell carcinomas. Sci. Transl. Med. 7:293ra104. doi: 10.1126/scitranslmed.aaa8507

Wen, Y. G., Wang, Q., Zhou, C. Z., Qiu, G. Q., Peng, Z. H., and Tang, H. M. (2010). Mutation analysis of tumor suppressor gene PTEN in patients with 
gastric carcinomas and its impact on PI3K/AKT pathway. Oncol. Rep. 24:89-95. doi: 10.3892/or_00000832

Wong, A. I., and Lo, Y. M. (2015). Noninvasive fetal genomic, methylomic, and transcriptomic analyses using maternal plasma and clinical implications. Trends Mol. Med. 21, 98-108. doi: 10.1016/j.molmed.2014.12.006

Xia, Y., Huang, C. C., Dittmar, R., Du, M., Wang, Y., Liu, H., et al. (2016). Copy number variations in urine cell free DNA as biomarkers in advanced prostate cancer. Oncotarget. 7, 35818-35831. doi: 10.18632/oncotarget.9027

Xu, Y., Song, Y., Chang, J., Zhou, X., Qi, Q., Tian, X., et al. (2018). High levels of circulating cell-free DNA are a biomarker of active SLE. Eur. J. Clin. Invest. 48:e13015. doi: 10.1111/eci.13015

Yanagita, M., Redig, A. J., Paweletz, C. P., Dahlberg, S. E., O'Connell, A., Feeney, N., et al. (2016). A prospective evaluation of circulating tumor cells and cell-free DNA in EGFR-mutant non-small cell lung cancer patients treated with erlotinib on a phase II trial. Clin. Cancer Res. 22, 6010-6020. doi: 10.1158/1078-0432.CCR-16-0909

Yeo, W., Wong, N., Wong, W. L., Lai, P. B., Zhong, S., and Johnson, P. J. (2005). High frequency of promoter hypermethylation of RASSF1A in tumor and plasma of patients with hepatocellular carcinoma. Liver Int. 25, 266-272. doi: 10.1111/j.1478-3231.2005.01084.x

Yuan, M., Huang, L.-L., Chen, J.-H., Wu, J., and Xu, Q. (2019). The emerging treatment landscape of targeted therapy in non-small-cell lung cancer. Signal Transduct. Target. Ther. 4:61. doi: 10.1038/s41392-019-0099-9

Zang, Z. J., Cutcutache, I., Poon, S. L., Zhang, S. L., McPherson, J. R., Tao, J., et al. (2012). Exome sequencing of gastric adenocarcinoma identifies recurrent somatic mutations in cell adhesion and chromatin remodeling genes. Nat. Genet. 44, 570-574. doi: 10.1038/ng.2246

Zhang, D., Gao, M., Jin, Q., Ni, Y., and Zhang, J. (2019). Updated developments on molecular imaging and therapeutic strategies directed against necrosis. Acta Pharm. Sin. B. 9:455-468. doi: 10.1016/j.apsb.2019.02.002

Zhang, J., Li, J., Saucier, J. B., Feng, Y., Jiang, Y., Sinson, J., et al. (2019). Non-invasive prenatal sequencing for multiple Mendelian monogenic disorders using circulating cell-free fetal DNA. Nat. Med. 25, 439-447. doi: 10.1038/s41591-018-0334-x

Zhang, J., Tong, K. L., Li, P. K., Chan, A. Y., Yeung, C. K., Pang, C. C., et al. (1999). Presence of donor- and recipient-derived DNA in cell-free urine samples of renal transplantation recipients: urinary DNA chimerism. Clin. Chem. 45, 1741-1746. doi: 10.1093/clinchem/45.10.1741

Zhang, S., Lu, X., Shu, X., Tian, X., Yang, H., Yang, W., et al. (2014). Elevated plasma cfDNA may be associated with active lupus nephritis and partially attributed to abnormal regulation of neutrophil extracellular traps (NETs) in patients with systemic lupus erythematosus. Intern. Med. 53, 2763-2771. doi: 10.2169/internalmedicine.53.2570

Zitt, M., Muller, H. M., Rochel, M., Schwendinger, V., Zitt, M., Goebel, G., et al. (2008). Circulating cell-free DNA in plasma of locally advanced rectal cancer patients undergoing preoperative chemoradiation: a potential diagnostic tool for therapy monitoring. Dis. Markers. 25, 159-165. doi: 10.1155/2008/5 98071

Zorofchian, S., Lu, G., Zhu, J. J., Duose, D. Y., Windham, J., Esquenazi, Y., et al. (2018). Detection of the MYD88 p.L265P mutation in the CSF of a patient with secondary central nervous system lymphoma. Front. Oncol. 8:382. doi: $10.3389 /$ fonc. 2018.00382

Conflict of Interest: The authors declare that the research was conducted in the absence of any commercial or financial relationships that could be construed as a potential conflict of interest.

Copyright (c) 2021 Yan, Guo, Wang, Adhikari, Zhu, Zhang, Zhou, Yu, Li and Zhang. This is an open-access article distributed under the terms of the Creative Commons Attribution License (CC BY). The use, distribution or reproduction in other forums is permitted, provided the original author(s) and the copyright owner(s) are credited and that the original publication in this journal is cited, in accordance with accepted academic practice. No use, distribution or reproduction is permitted which does not comply with these terms. 